\title{
PENINGKATAN SELF CARE MELALUI METODE EDUKASI BRAINSTORMING PADA PASIEN DIABETES MELITUS TIPE 2
}

\section{INCREASING SELF CARE THROUGH BRAINSTORMING EDUCATION METHOD IN DIABETES MELLITUS TYPE 2 PATIENTS}

\author{
Sarinah Sri Wulan', Busjra M. Nur ${ }^{2}$,Rohman Azzam ${ }^{3}$ \\ ${ }^{1}$ Fakultas Ilmu Keperawatan Universitas Muhammadiyah Jakarta \\ ${ }^{2}$ Fakultas Kedokteran Dan Kesehatan Universitas Muhammadiyah Jakarta \\ ${ }^{3}$ Fakultas Ilmu Keperawatan Universitas Muhammadiyah Jakarta \\ E-mail : sarina_sriwulan@yahoo.com
}

\begin{abstract}
Increasing Self Care Through Brainstorming Education Method In Diabetes Mellitus Type 2 Patients. Diabetes mellitus (DM) is a progressive chronic disease, characterized by the body's inability to metabolize carbohydrates, fats and proteins that cause hyperglycemia. Lack of patient understanding of the disease and self care can worsen the situation. Brainstorming education is a method that helps improve patient understanding. This study was to determine the effect of brainstorming education methods on self-care of DM type 2 patients. Using a Quasi experimental design of pre and post test with control group, with dependent t-test and independent t-test. Data collection using the Summary of Diabetes Self-Care Activities (SDSCA) questionnaire. Sample 104 respondents (intervention and control). There is an effect of brainstorming education on self-care type 2 diabetes mellitus ( $p$-value $=0.00$ ). There is an influence between age, income, length of illness, and education on type $2 \mathrm{DM}$ self care, the most dominant factor influencing self care is education (p-value $=0,000)$ with an OR value of 0.409 . While there was no influence between sex $(p=0.805)$ with self care type 2 DM patients. Brainstorming education can improve the self care of DM patients is expected to be applied in health services.
\end{abstract}

Keywords: Diabetes mellitus, brainstorming education method, self care

\begin{abstract}
Abstrak Peningkatan Self Care Melalui Metode Edukasi Brainstorming Pada Pasien Diabetes Mellitus Tipe 2: Diabetes mellitus (DM) merupakan penyakit kronis yang progresif, ditandaiketidakmampuan tubuh melakukan metabolisme karbohidrat, lemak dan protein yang mengakibatkan hiperglikemi. Kurangnya pemahaman pasien terhadap penyakit dan self care-nya dapat memperburuk keadaan. Edukasi brainstorming menjadi metode yang membantu peningkatan pemahaman pasien. Penelitian ini untuk mengetahui pengaruh metode edukasi brainstorming terhadap self care pasien DM tipe 2. Menggunakan desain Quasi eksperimen pre and post test with kontrol group, dengan uji dependent t-test dan uji independen t-test. Pengumpulan data menggunakan kuesioner Summary of Diabetes Self-Care Activities (SDSCA). Sampel 104 responden (intervensi dan kontrol). Ada pengaruh edukasi brainstorming terhadap self care diabetes melitus tipe 2 ( $p$-value $=$ 0,00 ). Ada pengaruh antara umur, pendapatan, lama sakit, dan pendidikan terhadap self care DM tipe 2 , faktor yang paling dominan mempengaruhi self care yaitu pendidikan $(p$-value $=0,000)$ dengan nilai $\mathrm{OR}=0,409$. Sementara tidak ada pengaruh antara jenis kelamin $(p=0,805)$ dengan self care pasien DM tipe 2. Edukasi brainstorming dapat meningkatkan self care pasien DM diharapkan dapat diterapkan di pelayanan kesehatan.

Kata Kunci : Diabetes mellitus, metode edukasi brainstorming, self care
\end{abstract}

\section{PENDAHULUAN}

Tingginya tingkat pasien DM disertai jumlah komplikasi yang dialami akan berpengaruh pada penurunan kualitas hidup manusia didunia. DM merupakan penyakit kronis yang progresif dimana ditandai dengan ketidak mampuan tubuh untuk melakukan metabolisme karbohidrat, lemak dan protein yang akan mengarah ke hiperglikemi/kadar gula dalam darah tinggi (Black \& Hawk; 2014).

Estimasi DM didunia menurut World Health Organization (WHO) (umur 20-79 th) pada tahun 2015 diabetes terjadi pada 415 juta orang dan akan terus meningkat menjadi 642 juta pada tahun 2040. Hampir $80 \%$ orang DM ada dinegara berpenghasilan rendah dan menengah (IDF atlas 
2017). Indonesia dengan jumlah total populasi sekitar 265 juta jiwa tahun 2018 angka kejadian DM meningkat. Riset Kesehatan Dasar (RISKESDAS) tahun 2018 oleh Kementrian Kesehatan RI memaparkan DM mengalami kenaikan dari 6,9\% (tahun 2013) menjadi 8,5\% di (tahun 2018). Peningkatan prevalensi penyakit tidak menular ini berhubungan dengan pola hidup yang tidak sehat, antara lain merokok, konsumsi minuman beralkohol, aktivitas fisik yang kurang, serta kurang konsumsi buah dan sayur. Provinsi Lampung DM menempati urutan ke 8 dari sepuluh penyakit terbanyak pada tahun 2015, hasil penelitian di Puskesmas Rawat Inap Kemiling Bandar Lampung didapatkan bahwa pasien dengan diabetes mellitus sebanyak 163 pasien selama 2 bulan terhitung dari tanggal 04 maret sampai dengan 05 mei 2019 yang tercatat datang berobat dengan berbagai komplikasi.

Komplikasi DM tipe 2 ini dapat mempengaruhi seluruh aspek kehidupan penderitanya dan memiliki peningkatan risiko terjadinya komplikasi seperti penyakit jantung, stroke, neuropati di kaki yang dapat meningkatkan kejadian ulkus kaki infeksi bahkan keharusan untuk amputasi, retinopati, gagal ginjal dan dapat mengancam jiwa bahkan kematian apabila tidak segera ditangani dan dilakukan pengontrolan yang tepat. Bigdeli (2016) menjelaskan masalah tersebut terjadi akibat kurangnya self care yang baik. Beberapa faktor yang dapat mempengaruhi self care seseorang diantaranya usia, pendidikan, pengetahuan, hubungan pasien dengan dokter, dan lama menderita DM. Penelitian lain memaparkan jenis kelamin dan pendapatan juga menjadi faktor yang mempengaruhi self care pasien DM (Ayele,2012; Kusniati dalam Putri,2017).

Self care adalah prilaku yang dilakukan oleh seseorang dengan ataupun beresiko DM agar bisa atau berhasil dalam mengelola penyakitnya sendiri (Shrivastava, 2013). Self care ini bisa diperoleh dari informasi yang diberikan oleh tenaga kesehatan melalui edukasi.Pentingnya suatu metode dalam memberikan edukasi kesehatan khususnya tentang self carepasien DM tipe 2. Edukasi yang diberika kepada klien dan keluarga merupakan peran primer seorang perawat, karenanya edukasi merupakan management umum tanpa obat ataupun yang sifatnya promotif (Bastable, 2006).

Standar edukasi klien dalam institusi pelayanan keperawatan mewajibkan seorang perawat dan tim kesehatan disetiap institusi menyusun suatu metode edukasi yang mencakup teori dari berbagai topik pengobatan misalnya diit, dan asuhan keperawatan lainnya. Metode edukasi menjadi syarat penting untuk keberhasilan materi yang diberikan, berikut beberapa metode yang dapat digunakan yaitu bimbingan dan penyuluhan (guidance and counselling), wawancara (interview), seminar, ceramah, diskusi kelompok, roleplay, simulation game, dan brainstorming (Notoatmodjo, 2012).

Perawatan diri/ self care dalam mengelola penyakit DM dapat mengatasi masalah kesehatan yang mengancam. Self Care yang baik dan benar pada pasien DM tipe 2 sangat diperlukan dalam upaya pencegahan terjadinya komplikasi. Keberhasilan self care diperoleh dari partisipasi pasien, keluarga dan masyarakat melalui informasi pendidikan kesehatan / edukasi.

Edukasi yang diberikan kepada pasien DM tipe 2 merupakan suatu proses yang memfasilitasi pengetahuan, ketrampilan, dan kemampuan perawatan diri pasien. Berbagai pilihan metode edukasi yang diberikan kepada pasien menjadi salah satu cara yang diguna untuk tercapainya pembelajaran yang baik sehingga dapat diserap dan dilaksanakan oleh pasien. Salah satu metode yang digunakan adalah metode edukasi brainstorming atau disebut juga dengan metode curah pendapat yaitu suatu metode pengumpulan sejumlah besar gagasan dari sekelompok orang dalam waktu singkat untuk mengungkapkan sebuah idenya (Sani,2014 dalam Maulidiyana,2018).

\section{METODE}

Penelitian ini menggunakan desain Quasi eksperimen pre and post test with control group, dengan satu macam perlakuan. Desain ini dilakukan pre test untuk pengukuran awal kedua 
kelompok sebelum dimulai perlakuan menggunakan kuesionerSummary of Diabetes Self Care Activities (SDSCA) dengan 17 pertanyaan tentang diit, olah raga, perawatan kaki, kontrol gula darah dna minum obat. Setelah itu kelompok intervensi diberikan edukasi brainstorming tentang self care pasien diabetes melitus tipe 2. Sementara kelompok kontrol tidak diberikan perlakuan secara khusus tetapi secara umum sesuai Puskesmas tempat kontrol. Setelah kelompok menjalankan self care selama 7 hari kedepan kemudian dilakukan pengukuran post test dengan kuesioner yang sama.

Populasi dpenelitian ini adalah seluruh pasien diabetes mellitus tipe 2 yang datang kontrol ke puskesmas yaitu 235 pasien. Tehnik pengambilan sampel menggunakan non probability sampling yaitu Consecutive Sampling. Jumpah sampel yang ditentukan dengan menggunakan rumus uji beda dua mean. Peneliti mengambil standar devisiasi dari penelitian Abumasoudi (2014) untuk dimasukan kedalam rumus, sehingga diperoleh sampel sebanyak 104 terdiri dari kelompok intervensi dan kontrol. Kriteria inklusi yang ditetapkan dapat komunikasi, dapat melihat, membaca dan menulis, penderita diabetes mellitus tipe 2, pasien rawat jalan, pasien yang bersedia/ komitmen meluangkan waktu untuk mengikuti edukasi brainstorming, pasien yang menyatakan tidak menjalankan salah satu kegiatan komponenself care (Pengaturan diet, olah raga, kontrol gula darah, perawatan kaki, dan patuh terhadap therapy).

\section{HASIL}

Penelitian ini diperoleh hasil bahwa tabel 1Menjelaskan kelompok intervensi dan kelompok kontrol rata-rata umur 55-57 tahun, dengan pendapatan rata-rata $\mathrm{Rp} 2.083 .000-\mathrm{Rp} 2.350 .00$ dan lama sakit rata-rata 3-5 tahun, pada tabel 2 . mayoritas didominasi berjenis kelamin perempuan dengan tingkat pendidikan SLTA/PT.
Tabel 1. Karateristik rata-rata responden berdasarkan usia, pendapatan dan lama sakit

\begin{tabular}{lcccccc}
\hline \multicolumn{1}{c}{ Variabel } & Mean & Median & SD & Min & Max & N \\
\hline Umur Responden & & & & & & \\
$\quad$ a. Intervensi & 55,35 & 57,0 & 9,313 & 31 & 77 & 52 \\
b. Kontrol & 57,96 & 57,50 & 8,849 & 38 & 76 & 52 \\
\hline $\begin{array}{l}\text { Pendapatan Responden } \\
\text { a. Intervensi }\end{array}$ & 2,350 & 2 & 146,2 & 200 & 6000 & 52 \\
b. Kontrol & 2,083 & 2 & 121,6 & 200 & 5000 & 52 \\
\hline Lama Sakit Responden & 3,971 & 3 & 3,087 & 4 & 10 & 52 \\
$\quad \begin{array}{l}\text { a. Intervensi } \\
\text { b. Kontrol }\end{array}$ & 5,190 & 5 & 4,128 & 2 & 15 & 52 \\
\hline
\end{tabular}

Tabel 2. Distribusi kareteristik responden berdasarkan jenis kelamin dan pendidikan

\begin{tabular}{lcccc}
\hline \multirow{2}{*}{ Variabel } & \multicolumn{2}{c}{$\begin{array}{c}\text { Kelompok Intervensi } \\
(\mathbf{n = 5 2})\end{array}$} & \multicolumn{2}{c}{$\begin{array}{c}\text { Kelompok Kontrol } \\
(\mathbf{n = 5 2})\end{array}$} \\
\cline { 2 - 5 } & $\sum$ & $\mathbf{\%}$ & $\sum$ & $\mathbf{\%}$ \\
\hline Jenis Kelamin & & & & \\
a. Laki-laki & 15 & 28,8 & 19 & 36,5 \\
b. Perempuan & 37 & 71,2 & 33 & 63,5 \\
\hline Pendidikan & & & & \\
a. SD/ SLTP & 16 & 30,8 & 10 & 19,2 \\
b. SLTA/ PT & 36 & 69,2 & 42 & 80,8 \\
\hline
\end{tabular}

Tabel 3 dan 4 dibawah menjelaskan rata-rata self care pada pasien intervensi 52,23 pre test sedangkan hasil post test 71,87 dengan hasil $p$ value $(0,000)$ yang dapat disimpulkan ada perbedaan yang signifikan antara pre dan post intervensi. Tabel 4 menjelaskan rata-rata self care pada pasien kontrol 55,29 pre test sedangkan nilai post test 56,38 ada perbedaan tetapi tidak signifikan dengan hasil $\mathrm{p}$-value $(0,397)$.

Tabel 3. Distribusi rata-rata self care pasien intervensi pre dan post

\begin{tabular}{|c|c|c|c|c|c|c|c|}
\hline \multirow{2}{*}{ Variabel } & \multirow{2}{*}{ Mean } & \multirow{2}{*}{ SD } & \multirow{2}{*}{ SE } & \multicolumn{2}{|c|}{ CI 95\% } & \multirow{2}{*}{ p-value } & \multirow{2}{*}{$\mathbf{N}$} \\
\hline & & & & Lower & Upper & & \\
\hline \multicolumn{8}{|l|}{ Self care } \\
\hline Pre Test & 52,23 & 12,826 & 1,779 & & & & 52 \\
\hline Post Test & 71,87 & 5,622 & 0,780 & $-23,090$ & $-16,180$ & 0,000 & 52 \\
\hline
\end{tabular}

Tabel 4. Distribusi rata-rata self care pasien kontrol pre dan post

\begin{tabular}{|c|c|c|c|c|c|c|c|}
\hline \multirow{2}{*}{ Variabel } & \multirow{2}{*}{ Mean } & \multirow{2}{*}{ SD } & \multirow{2}{*}{ SE } & \multicolumn{2}{|c|}{ CI 95\% } & \multirow{2}{*}{ p-value } & \multirow{2}{*}{$\mathrm{N}$} \\
\hline & & & & Lower & Upper & & \\
\hline \multicolumn{8}{|l|}{ Self Care } \\
\hline Pre Test & 55,29 & 12,541 & 1,739 & 3672 & 1470 & 0307 & 52 \\
\hline Post Test & 56,38 & 9,778 & 1,356 & $-5,0 / 2$ & $1,4 / 9$ & 0,597 & 52 \\
\hline
\end{tabular}

Tabel 5. Rata-rata perbedaan self care antara Kelompok Intervensi dan Kelompok Kontrol pre dan post 


\begin{tabular}{|c|c|c|c|c|c|c|c|}
\hline \multirow{2}{*}{ Variabel } & \multirow{2}{*}{ Mean } & \multirow{2}{*}{ SD } & \multirow{2}{*}{ SE } & \multicolumn{2}{|c|}{ CI 95\% } & \multirow{2}{*}{$p$-value } & \multirow{2}{*}{$\mathbf{N}$} \\
\hline & & & & Lower & Upper & & \\
\hline \multicolumn{8}{|l|}{ Pre Test } \\
\hline Intervensi & 55,23 & 12,826 & 1,779 & \multirow{2}{*}{$-7,992$} & \multirow{2}{*}{1,876} & \multirow{2}{*}{0,222} & 52 \\
\hline Kontrol & 55,29 & 12,541 & 1,739 & & & & 52 \\
\hline \multicolumn{8}{|l|}{ Post Test } \\
\hline Intervensi & 71,87 & 5,622 & 0,780 & \multirow{2}{*}{12,378} & \multirow{2}{*}{18,583} & \multirow{2}{*}{0,000} & 52 \\
\hline Kontrol & 56,38 & 9,778 & 1,356 & & & & 52 \\
\hline
\end{tabular}

Tabel diatas menjelaskan perbedaan self care antara Kelompok Intervensi dan Kelompok Kontrol diperoleh hasil pre test dengan p-value $(0,222)$ menunjukan tidak ada perbedaan antara kedua kelompok, sementara hasil post test diperoleh $p$-value (0.000) yang artinya ada perbedaan yang signifikan antara kelompok intervensi dan kelompok kontrol

\section{PEMBAHASAN}

\section{Karateristik responden}

Umur pada kelompok intervensi maupun kontrol dapat disimpulkan kedalam kriteria lansia awal. Hal ini sejalan dengan pendapat Perkeni (2017),Wardiah \& Emilia (2018), Damayanti (2015) bahwa kelompok usia 45 tahun ke atas adalah kelompok yang beresiko tinggi mengalami DMsemakin bertambah umur semakin beresiko mengalami diabetes mellitus dibandingkan umur yang paling muda. Proses menua yang berlangsung setelah usia 30 tahun mengakibatkan perubahan anatomis, fisiologis dan biokimia. Perubahan dimulai dari tingkat sel, berlanjut pada tingkat jaringan dan akhirnya pada tingkat organ yang dapat mempengaruhi fungsi homeostasis. Komponen tubuh yang dapat mengalami perubahan adalah sel beta pankreas yang menghasilkan hormon insulin. Selain itu kenaikan glukosa darah secara fisiologis terjadi karena penurunan sekresi sehingga menyebabkan kurang optimalnya tubuh dalam mengendalikan glukosa dalam darah (Setianingsih, 2017.,Suyono, 2011., Karavidas, 2010)

Jenis kelamin mayoritas terjadi pada perempuan baik intervensi dan kontrol.Sejalan dengan penelitian Alghadir,et all dalam Riyadh, (2012)., Fatimah, (2015)., Setianingsih, (2017) menyatakan bahwa perempuan memiliki resiko yang lebih tinggi dibandingkan dengan laki-laki. Hal ini karena wanita secara fisik memiliki peluang peningkatan indeks massa tubuh yang lebih tinggi selain itukurang melakukan aktifitas fisik semakin jarang melakukan aktivitas fisik maka gula yang dikonsumsi juga akan semakin lama terpakai, akibatnya prevalensi peningkatan kadar gula dalam darah juga akan semakin tinggi (Hakim, 2018).

Berbeda dengan Kekenusa (2013) dan Oxyandi dalam Putri (2017) bahwa sebagian besar responden yang menderita DM adalah laki-laki. Hal tersebut karena laki-laki dipengaruhi oleh distribusi lemak dalam tubuh khususnya daerah di sekitar perut sehingga memicu obesitas sentral yang lebih beresiko memicu terjadinya gangguan metabolisme.

Pendidikan mayoritas terjadi pada tingkatSLTA/PT. Hasil ini sejalan dengan penelitian Allorerung, (2016)., Mamangkey, (2014)., dan Endriyani (2012) yang mengungkapkan bahwa tidak terdapat hubungan antara pendidikan dengan kejadian dan pencegahan komplikasi DM tipe 2. Berbeda halnya dengan Basri, (2016)., Hakim., (2018) dan Feleaa, (2014) menyatakan ada hubungan antara pendidikan dengan kejadian komplikasi diabetes mellitus. Semakin tinggi pendidikan maka semakin baik tingkat pencegahan terhadap suatu penyakit dibandingkan dengan yang berpendidikan rendah selain itu dengan pendidikan yang tinggi kemampuan untuk menyerap informasi tentang keshatan akan lebih baik sehingga dengan pendidikan tinggi mampu meningkatkan pencegahan komplikasi dari diabetes serta meningkatkan daya deteksi terhadap kejadian diabetes (Cai Le, 2011).

Pendapatansetiap bulan pada kedua kelompok masih rata-rata dibawah UMR. Sejalan dengan penelitian yang dilakukan Mongisidi (2014), Brown et al dalam Edriani (2012), menyatakan bahwa responden memiliki penghasilan < UMPberhubungan pada rendahnya tingkat kesehatan baik emosi maupun fisik. Akibatnya, masyarakat cenderung memiliki resiko terjadinya penyakit kardiovaskular dan kontrol glikemik yang buruk. 
Lama sakit rata-rata 3-5 tahun baik responden intervensi maupun kontrol. Sejalan dengan penelitianHakim, (2018) lama DM menunjukkan 5 dan lama menderita diabetes melitus memiliki hubungan dengan pengetahuan seseorang mengenai pencegahan komplikasi DM (Notoadmojo, 2011).

\section{Pengaruh Eukasi brainstorming terhadap kemampuan self crae pada pasien diabetes melitus tipe 2}

Ada perbedaan rata-rata self care pada kelompok intervensi sebelum dan sesudah dilakukan edukasi brainstorming. Metode ini adalah tekhnik atau cara mengajar yang dilakukan oleh guru/ edukator didalam kelas/ tempat yaitu dengan cara, melontarkan suatu masalah ke kelas oleh guru/ edukator, kemudian kelompok menjawab atau menyatakan pendapat, serta mendapatkan banyak ide dari kelompok manusia dalam waktu yang sangat singkat (Roestiyah,2012).

Keunggulan dari metode ini menurut Primadyaningsi, (2016) yaitu Membangkitkan semangat belajar dan suasana menyenangkan, Mengembangkan ide kreatif masing-masing peserta kelompok, Melatih peserta kelompok berpikir secara cepat dan logis. Meningkatkan partisipasi peserta kelompok dalam menerima pelajaran. Menjadikan kelompok aktif untuk menyatakan pendapatnya. Edukasi brainstorming ini merupakan salah satu strategi intervensi keperawatan yang bersifat promotif yang diberikan kepada klien melalui pembentukan kelompok yang memiliki masalah yang sama. Intervensi ini berfokus kepada penyelesaian masalah self care pada pasien DM. Hal ini mendukung teori keperawatan orem dimana akan diberikan jika pasien ketergantungan/ tidak mampu atau terbatas dalam melakukan self care secara efektif.

Sejalan dengan penelitian Chrisanto (2016) yaitu adanya perbedaan yang signifikan rata-rata self care kelompok intervensi sebelum dan setelah dilakukan edukasi brainstorming. Selain ini, jurnal internasional oleh Alaa (2012), menyatakan bahwa perawat berperan dalam memberikan suatu promosi kesehatan dengan melakukan penyuluhan.

Penelitian ini tidak ada perbedaan rata-rata self care pada kelompok kontrol sebelum dan sesudah perlakuan. Sejalan dengan penelitian Chrisanto, (2016)pada penelitiannya diperoleh tidak ada perbedaan yang signifikan rata-rata self care kelompok kontrol sebelum dan setelah dilakukan edukasi standart puskesmas. Hasil ini diasumsikan terjadi karena pasien kontrol tidak mendapatkan edukasi brainstorming sehingga pemahaman responden terhadap self care DM kurang. Selain itu pengamatan peneliti pada responden kontrol tidak seluruhnya mendapatkan penjelasan tenaga medis tentang self care pasien diabetes tipe 2 dimana hal ini juga bisa berpengaruh kepada pengetahuan pasien terhadap menjalankan self care dengan baik.

Penelitian ini diperoleh ada perbedaan rata-rata self careantara kelompok intervensi dan kelompok kontrol sesudah dilakukan edukasi brainstorming.Selisih peningkatan yang terjadi pada kelompok intervensi lebih tinggi dibandingkan kelompok kontrol. Pelaksanaan edukasi pada kelompok kontrol sesuai dengan standar puskesmas dalam bentuk penjelasan secara langsung tanpa persiapan yang khusus, serta tidak semua responden mendapatkan informasi yang sama satu sama lain sehingga belum tentu mendapatkan pemahaman yang sama tentang self care DM dari petugas kesehatan.

Kemampuan untuk melakukan self care yaitu melalui proses belajar dengan pemberian pengetahuan melalui metode belajar brainstorming yang diberikan kepada pasien guna meningkatkan aspek kognitif dan afektif, secara simultan akan mempengaruhi peningkatan perilaku melakukan self care yang baik. Self care merupakan salah satu teori keperawatan yang dikembangkan oleh Dorothea Orem. Kerangka kerja teori self care Orem berfokus pada peningkatan kemampuan klien untuk meningkatkan perilaku yang berpengaruh terhadap kesehatannya. Self care activity pada penderita DM merupakan tindakan yang dilakukan secara mandiri oleh penderita DM 
untuk meningkatkan pengaturan gula darah guna mencegah komplikasi (Sause, 2015 dan Bai 2009).

Self care pada penderita diabetes melitus tipe 2 meliputi pengaturan pola makan dan diet yang ketat, pada pasien DM perlu ditekankan keteraturan makan $3 \mathrm{~J}$ yaitu teratur jadwal makan, teratur jenis makanan dan teratur jumlah makanan, Melakukan latihan jasmani secara rutin, pemantauan gula darah secara kontinu, perawatan kaki,Pengobatan yang teratur, dan konsumsi obat hipoglikemik oral (Toobert,2000 dalam Luthfa 2019, Srikartika, 2016, Perkeni, 2011).

Peningkatan self care diabetik pada kelompok perlakuan menjadi lebih tinggi dibandingkan kelompok kontrol, karena selama masa penelitian di Puskesmas Rawat Inap Kemiling responden mendapatkan pendidikan kesehatan tentang penyakitnya secara lebih terstruktur, yaitu melalui edukasi brainstorming. Hasil yang didapatkan mempertegas bahwa melalui pendidikan kesehatan dapat meningkatkan kemampuan seseorang untuk meningkatkan pengetahuan, keterampilan, dan sikap diri mereka serta selama proses dan setelah dilakukannya pendidikan kesehatan terjadi proses adopsi perilaku dari responden terkait tema edukasi yang diberikan yang mendukung perawatan diri mereka.

\section{Faktor counfounding}

Tidak ada pengaruh yang signifikan antara umur dengan kemampuan self care pasien diabetes tipe 2. Usia tua memiliki self care yang lebih baik dan teratur dibandingkan pasien yang usianya lebih muda ini dikarenakan peningkatan usia merupakan terjadinya proses kematangan dan kedewasaan seseorang sehingga klien akan berpikir lebih rasional tentang manfaat yang akan didapatkan apabila melaksanakan aktifitas self care-nya dengan adekuat. Usia lanjut juga erat dengan aktivitas fisik, kepatuhan terhadap diet dan perawatan kaki (Kusniati, 2011 \& vocilia, 2015 dalam Pitri 2017).

Berbeda dengan hasil penelitian Prasetyani (2018), menunjukkan ada pengaruh yang signifikan antara umur dengan kemampuan selfcare. Pasien yang berusia tua cenderung mengalami penurunan fisik dan kognitif yang dapat mempengaruhi kemampuannya dan keaktifannya untuk melakukan aktivitas self-care. Selain itu, timbulnya komplikasi pada usia tua juga akan mempengaruhi kemampuan pasien dalam melakukan self-care. Kemampuan pasien akan meningkat jika pasien aktif mengikuti kegiatan yang dapat meningkatkan pengetahuan dan motivasi untuk melakukan aktivitas self-care, seperti kegiatan Prolanis atau Persadia dan lainnya.

Ada pengaruh yang signifikan antara pendapatan dengan kemampuan self care pasien diabetes tipe 2. Penelitian ini sejalan dengan hasil penelitian yang dilakukan oleh Fajrunni'mah (2017), dan Amelia (2014) menunjukkan tingkat pasien pendapatannya tinggi, lebih mudah untuk membeli makanan sesuai diet diabetes. Hal yang sama dijelaskan oleh Aggarwal, (2015) menjelaskan faktor sosial ekonomi sangat penting pengaruhnya terhadap manajemen pencegahan diabetes. Pendapatan berkaitan dengan kemampuan dalam melakukan pemeriksaan, penyediaan makanan dan pengobatan. Kemampuan pasien dalam melakukan pemeriksaan gula darah dan penyediaan makanan sesuai diit diabetes merupakan kemampuan pasien dalam melakukan atau mengelola self care dengan baik, dengan harapan resiko komplikasi yang lebih parah tidak terjadi.

Berbeda dengan penelitian Harahap (2010), dan Sari (2017), Ayele (2012) dan Prasetyani et al (2018) bahwa tidak terdapat hubungan yang bermakna antara pendapatan dengan pencegahan komplikasi diabetes mellitus. Umumnya pasien DM dengan penghasilan yang tinggi kurang patuh terhadap self care-nya dibandingkan dengan pasien DM dengan penghasilan rendah. Hal ini dikarenakan penderita dengan penghasilan tinggi memiliki hidup yang lebih beresiko dibandingkan dengan pasien DM yang berpenghasilan lebih rendah.

Ada pengaruh yang signifikan antara lama sakit dengan kemampuan self care pasien diabetes tipe 2 di Puskesmas Rawat Inap Kemiling Bandar Lampung.Sejalan dengan hasil penelitian Kusniawati, (2011) dan Emilia (2014) menjelaskan 
pasien DM yang menderita $>10$ tahun menunjukan self care lebih baik daripada pasien yang menderita $<10$ tahun. Asumsi penelitiartinyasemakin lama pasien DM sakit semakin self care-nya meningkat.

Berbeda dengan hasil penelitian Prasetyani, (2018) menunjukkan hasil tidak ada hubungan antara lama DM dengan kemampuan self-care. Lamanya pasien menderita DM berpengaruh terhadap terjadinya komplikasi. Hal ini yang menyebabkan terjadinya kelemahan fisik hingga pasien tidak mampu melakukan self-care secara tepat dan mandiri. Selain masalah komplikasi, faktor kejenuhan karena lamanya menderita DM juga dapat mempengaruhi kemampuan dan kemauan dalam melakukan self-care (Bertalina \& Purnama, 2016)

Tidak ada pengaruh yang signifikan antara jenis kelamin dengan kemampuan self care pasien diabetes tipe 2 di Puskesmas Rawat Inap Kemiling Bandar Lampung. Sejalan dengan Kusniawati, (2011) bahwa tidak ada pengaruh yang signifikan antara jenis kelamin dengan perilaku self care DM. Hal ini dikarenakan pada dasarnya self care harus dilakukan oleh siapa saja yang menderita DM, baik itu perempuan maupun laki-laki. Penderita DM perempuan biasanya lebih perhatian terhadap kondisi penyakitnya, begitu pula dengan penderita DM laki-laki yang harus memiliki tanggung jawab penuh untuk mengelola penyakitnya sendiri. Lakilaki maupun perempuan harus melakukan self care untuk kontrol gula darah agar tetap terjaga dalam normal.

Ada pengaruh yang signifikan antara pendidikan dengan kemampuan self care pasien diabetes tipe 2 di Puskesmas Rawat Inap Kemiling Bandar Lampung. Pendidikan yang akan menghasilkan pengetahuan mempunyai pengaruh sebagai dorongan awal seseorang dalam berperilaku. Pengetahuan dapat menjadikan seseorang memiliki kesadaran sehingga akan berperilaku sesuai pengetahuan yang dimiliki. Perubahan perilaku yang didasari oleh pengetahuan akan bersifat langgeng karena didasari oleh kesadaran mereka sendiri bukan paksaan (Notoatmodjo, 2011). Pengetahuan atau pendidikan merupakan faktor yang sangat penting untuk pengelolaan self care DM. Studi menyatakan bahwa kurangnya pengetahuan akan menghambat pengelolaan self care. Individu dengan tingkat pendidikan yang rendah akan mengalami kesulitan dalam belajar merawat diri dengan DM (Kisokanth, 2013 \& Ayele, 2012).

Penelitian ini sejalan dengan penelitian Haryono,(2018) menyatakan ada pengaruh yang signifikan antara pendidikan kesehatan tentang diet DM terhadap kepatuhan pasien DM. Kepatuhan adalah ketaatan terhadap makanan dan minuman yang dikonsumsi orang tiap hari dalam keadaan sehat untuk menjaga kesehatan dan untuk mempercepat proses penyembuhan bagi orang yang sakit (Rusimah, 2011). Kepatuhan dalam pengaturan diet adalah salah satu komponen dalam pengelolaan self care pasien DM. Artinya jika individu dengan DM patuh terhadap diet maka dikatakan sudah mampu untuk menjalankan self care nya dengan baik.

Berbeda dengan penelitian Prasetyani, (2018) menunjukan tidak ada hubungan antara pendidikan dengan kemampuan self care, untuk melakukan self care pasien tidak hanya membutuhkan pendidikan akan tetapi juga membutuhkan motivasi dan dukungan baik dari keluarga maupun lingkungan. Motivasi dan dukungan ini akan dapat meningkatkan kemampuan pasien dalam melakukan self care (Mayberry, 2014 dalam Prasetyani,2018).Pasien dengan pendidikan tinggi akan memiliki sikap positif dan terbuka dalam menerima informasi sehingga pasien akan lebih aktif dalam melakukan perawatan diri seperti aktivitas self-care. Selain ini, ketenangan kondisi baik diri maupun lingkungan saat menerima pendidikan harus kondusif, sehingga informasi yang akan diterima pasien akan maksimal.

\section{KESIMPULAN}

Kesimpulan dari penelitian ini yaitu metode edukasi brainstorming memberikan peningkatan yang signifikan terhadap kemempuan self care pasien dengan diabetes mellitus tipe 2. Selain ini, dari beberapa faktor yang mempengaruhi 
kemampuan self care pasien, yang paling dominan mempengaruhi yaitu faktor pendidikan.

\section{SARAN}

Pelaksanaan edukasi brainstorming hendaknya dilakukan secara rutin dan terkontrol oleh tenaga kesehatan yang bertanggung jawab di Puskesmas, serta melaksanakan observasi langsung terhadap kemampuan self care yang dijalani oleh pasien.

\section{DAFTAR PUSTAKA}

Ayele K, Tesfa B, Abebe L, TilahunT,Girma E. Self Care Behavior among Patients with Diabetes in Harari, Eastern Ethiopia: The Health Belief Model Perspective. Public Health and Medical Sciences Jimma University.

2012.http://journal.plos.org/plosone/acticle?i $\mathrm{d}=10.1371 \% 2 \mathrm{f}$.Diakses pada tanggal 5 januari 2019.

Amelia, M.(2014).Analisis faktor-faktor yang mempengaruhi keluarga untuk memberikan dukungan kepada klien diabetes mellitus dalam menjalani diet. JOM PSIK vol. 1 No.2. Oktober 2014.

Aggarwal, B.(2015) Diabetes Prevention and Management. North Carolina's Guide to Diabetes Prevention and Management 20152020

Basri, H. Wulandini, P. \& Saputra, R. (2016). Hubungan Pengetahuan Penderita Diabetes Melitus Terhadap Kejadian Luka Diabetes Melitus di Ruang Penyakit dalam RSUD.Arifin Achmad Pekanbaru. Jurnal Kesehatan. DIII Keperawatan Universitas Abdurrab

Bai YL, Chiou Cp, Chang YY. (2014). Self-Care Behaviour and Related Faktorin Older Peoplewith Type 2 Diabetes. JCN. 2009. http://www.ncbi.nlm.nih.gov/pubmed/19930 088. Diakses 15 januari 2019

Bertalina, Purnama. (2016). Hubungan lama sakit, pengetahuan, motivasi pasien dan dukungan keluarga dengan kepatuhan diet pasien Diabetes Mellitus. Jurnal Kesehatan, Volume VII, Nomer 2, 329-340

Black, M. Joyce dan Jane Hokanson Hawks. (2014). Keperawatan Medikal Bedah. Edisi
8, Jilid 2. Elsevier. Singapura : PT SalembaMedikaEmillia, E, A. 2014. Hubungan Dukungan Sosial Dan Perilaku Perawatan Diri Penyandang Diabetes Melitus Tipe 2. http://lib.ui.ac.id

Cai Le, Dong Jun, ShuZ hankun, Lu Yichun and Tao Jie. (2011). Socioeconomic Differences In Diabetes Prevalence, Awareness, and Treatment In Rural Southwest China. Tropical Medicine and International Health volume 16 no 9 pp 1070-1076 September 2011.

Crisyanto, E,Y. (2016) Tesis. Pengaruh Metode Edukasi Brainstorming terhadap self care pada klien congestive heart failure di RSUD Hi.Abdoel Moeloek Bandar Lampung.

Damayanti S. (2015) Diabetes Mellitus dan Penatalaksanaan Keperawatan. Yogyakarta: NuhaMedika.

Edriani, A. (2012). Hubungan Faktor Sosial Ekonomi \& Faktor yang Tidak \& Bisa Dimodifikasi Terhadap Diabetes Mellitus pada Lansia \& Prelansia Di Kelurahan Depok Jaya, Depok, Jawa Barat tahun 2012. Diakses pada tanggal 8 Januari 2017. http://lib.ui.ac.id

Emillia, E, A. (2014). Hubungan Dukungan Sosial Dan Perilaku Perawatan Diri Penyandang Diabetes Melitus Tipe 2. http://lib.ui.ac.id.

Fajrunni'mah, R. (2017).Faktor Pendukung dan Penghambat Penderita Diabetes Melitus dalam Melakukan Pemeriksaan Glukosa Darah. Bekasi :Politeknik Kesehatan Kementrian Kementrian Kesehatan Jakarta III.

Feleaa, M.G, Covrigb,M., Mirceab, and Naghib. (2014). Socioeconomic Status and Risk of Type 2 Diabetes Mellitus amongan Elderly Group Population in Romania.Procedia Economics and Finance $1061-67$.

Hakim, (2018). Dian Lukma. Publikas illmiah. Hubungan Tingkat Sosial Ekonomi: Pendidikan, Penghasilan dan Ffasilitas Dengan Pencegahan Komplikasi Kronis Pada Penyandang Diabetes Melitus..Eprints.ums.ac.id.

Harahap, E.R. (2010). Hubungan Pengetahuan dan Sikap Penderita Diabetes Melitus (DM) dengan Pemanfaatan Klinik Diabetes 
Melitus di Puskesmas Sering Kecamatan Medan Tembung Tahun 2010. Skripsi. Medan: Universitas Sumatera Utara

Haryono S. Suryati E,I. Mariyam R,S..(2018). Pendidikan kesehatan tentang diet terhadap kepatuhan pasien diabetes mellitus.Riset jurnal kesehatan. http://ejournal.poltekkessmg.ac.id/ojs/index. php/jrk. Diakses 1 januari 2019

International Diabetes Federation.(2017). IDF Diabetes Atlas Eighth Edition 2017. Isbn(vol.8).http://doi.org/10.1017/CBO9781 107415324.004 .

Kusniawati. (2011) Tesis Analisis Faktor yang Berkontribusi Terhadap Self Care Diabetes Pada Klien Diabetes Melitus Tipe 2 Di Rumah Sakit Umum Tangerang.Depok:FIKUI.http://lonar.ui.ac.id Kisokanth G, Prathapan S, Indrakumar J, Joseph J. (2014). Factors Influencing SelfManagement of Diabetes Melitus: a Review Article. Sri Lanka: Eastern University \& University of Sri Jayewardenepura. http://www.journalofdiabetology.org /Pages/Releases/FullTexts/TWELFTHISSU E/RA-1-JOD-13-018.aspx. Diakses pada tanggal 5 februari 2019

Mayberry, L. S. \& Osborn, C. Y. (2014). Family involvement is helpful and harmful to patients' self-care and glycemic control. Patient Education and Counseling, 97, 418 425

Mongisidi G. Hubungan Antara Status SosioEkonomi dengan Kejadian Diabetes Melitus Tipe 2 di Poli klinik Interna BLU RSUP Prof.Dr. R. D. Kandou Manado. Universitas Sam Ratulangi: Fakultas Kesehatan Masyarakat. 2014. http://fkm.unsrat.ac.id

Notoatmodjo,S. (2012). Metodologi Penelitian Kesehatan ISBN: 978-979-518-984-8. Jakarta:RinekaCipta

Perkeni. (2011). Konsensus pengelolaan dan pencegahan diabetes melitustipe 2 di Indonesia 2011. PB. Jakarta: Perkeni. http://dokumen.tips/documents/revisi-finalkonsensus-dm-tipe2 indonesia2011.html. Diaksestanggal 1 januari 2019

Primadyaningsih K et all. (2016). Penggunaan Metode Pembelajaran Brainstorming Untuk Meningkatkan Keterampilan Menulis Pantun. PGSD FKIP Universitas Sebelas Maret.
Prasetyani et all (2018). Hubungan Karakteristik, Pengetahuan Dan Dukungan Keluarga Dengan Kemampuan Self-Care Pada Pasien Dm Tipe 2 Di Puskesmas Cilacap Tengah 1 Dan 2. Jurnal Kesehatan Al-Irsyad (JKA), Vol. XI, No. 1. Maret 2018

Putri L Riana. (2017). Skripsi.Gambaran Self Care Penderita Diabetes Melitus (DM) Di Wilayah Kerja Puskesmas Srondol Semarang.

Http://D:/Skripsi_Linda_Riana_Putri.Pdf.

Sari, H.N. (2017). Hubungan Karakteristik Demografi dengan Self-Care Diabetes Melitus pada pasien Diabetes Melitus di RSUP H. Adam Malik Medan. Journal Kesehatan. Medan : Universitas Sumatera Utara.

Setianingsih R.S.D. (2017) Pengaruh Pendidikan Kesehatan Perawatan Kaki Diabetik Dengan Metode Demonstrsi Terhadap Kemampuan Merawat Kaki Pada Pasien Diabetes Melitus di RSUP Dr.Soeradji Tirto Negoro Klaten,.

Souse, V.D., \& Zauszniewski, J.A. (2015).Toward atheory of diabetes self care management. The Journal of Theory Construction \& Testing,

Suyono, S. (2011). Penatalaksanaan DM Terpadu Patofisiologi DM (Ed 2). Jakarta : FKUI

Shrivastava S.R., Shrivastava S.H.,\& Ramasamy,J. (2013). Role of self care in management of diabetes mellitus. Journal of diabetes \& metabolic disorders. http//:www.jdmdonline.com/content/12/1/14

Srikartika, V.M., Cahya, A.D. \& Hardiati, R.S.W. (2016). Analisis faktor yang memepengaruhi kepatuhan penggunaan obat pasien diabetes mellitus tipe 2. Jurnal Managemen dan Pelayanan Farmasi.

Luthfa Iskim. (2019). Implementasi Self care Activity Penderita Diabetes Mellitus di Wilayah Puskesmas Bangetayu Semarang. https://doi.org/10.22435/bpk.v47i1.779

Roestiyah.(2012). Strategi Belajar Mengajar. Jakarta :Rineka Cipta

Riyadi S, Sukarmin. (2008) Asuhan Keperawatan Pada Pasien dengan Gangguan Eksokrin \& Endokrin Pada Pankreas. Yogyakarta: Graha Ilmu.

RISKESDAS. (2018). Hasil Utama 10 Penyakit terbanyak di Indonesia 
16 Jurnal Ilmiah Kesehatan, Volume IX, Nomor 1, Januari 2020, hlm 7-16

Wardiah \& Emilia Esi. (2018). Faktor Resiko Diabetes Melitus Pada Wanita Usia Produktif Di Wilayah Kerja Puskesmas Langsa Lama Kota Langsa Aceh.http://ejournal.helvetia.ac.id/index.php /jkg.http://ejournal.helvetia.ac.id/index.php/j $\mathrm{kg}$. 